\title{
Vitamin A deficiency during pregnancy of HIV infected and non-infected women in tropical settings of Northwest Ethiopia
}

\author{
Andargachew Mulu ${ }^{1,2^{*}}$, Afework Kassu', Kahsay Huruy ${ }^{3}$, Birhanemeskel Tegene ${ }^{3}$, Gashaw Yitayaw ${ }^{3}$, \\ Masayo Nakamori ${ }^{4}$, Nguyen Van Nhien ${ }^{5}$, Assegedech Bekele ${ }^{6}$, Yared Wondimhun ${ }^{7}$, Shigeru Yamamoto ${ }^{8}$ and \\ Fusao Ota ${ }^{9}$
}

\begin{abstract}
Background: Vitamin A deficiency (VAD) is known to be a major public health problem among women of reproductive age in South East Asia and Africa. In Ethiopia, there are no studies conducted on serum vitamin A status of HIV-infected pregnant women. Therefore, the present study was aimed at determining the level of serum vitamin A and VAD among pregnant women with and without HIV infection in tropical settings of Northwest Ethiopia.

Methods: In this cross-sectional study, blood samples were collected from 423 pregnant women and from 55 healthy volunteers who visited the University of Gondar Hospital. Serum concentration of vitamin A was measured by high performance liquid chromatography.

Results: After controlling for total serum protein, albumin and demographic variables, the mean \pm SD serum vitamin A in HIV seropositive pregnant women $(0.96 \pm 0.42 \mu \mathrm{mol} / \mathrm{L})$ was significantly lower than that in pregnant women without HIV infection $(1.10 \pm 0.45 \mu \mathrm{mol} / \mathrm{L}, \mathrm{P}<0.05)$. Likewise, the level of serum vitamin $A$ in $H I V$ seropositive non-pregnant women $(0.74 \pm 0.39)$ was significantly lower than that in HIV negative non-pregnant women $(1.18 \pm 0.59 \mu \mathrm{mol} / \mathrm{L}, \mathrm{P}<0.004)$. VAD (serum retinol $<0.7 \mu \mathrm{mol} / \mathrm{L}$ ) was observed in $18.4 \%$ and $17.7 \%$ of HIV infected and uninfected pregnant women, respectively. Forty six percent of non-pregnant women with HIV infection had VAD while only 28\% controls were deficient for vitamin $A(P=0.002)$.

Conclusion: The present study shows that VAD is a major public health problem among pregnant women in the tropical settings of Northwest Ethiopia. Considering the possible implications of VAD during pregnancy, we recommend multivitamin (which has a lower level of vitamin A) supplementation in the care and management of pregnant women with or without HIV infection.
\end{abstract}

Keywords: Vitamin A deficiencies, pregnancy, HIV infection, Ethiopia

\section{Background}

Vitamin A deficiency (VAD) is known to be a significant public health problem around the world and it is particularly serious among women of reproductive age in South-East Asia and Africa [1-4]. It has now become evident that VAD in women has negative consequences

\footnotetext{
* Correspondence: andargachewmulu@yahoo.com

'Department of Microbiology, Immunology and Parasitology, College of Medicine and Health Sciences, University of Gondar, P. O. Box 196, Gondar, Ethiopia

Full list of author information is available at the end of the article
}

on their health status as well as on their infants [3,4]. The link between VAD morbidity and mortality from infectious diseases [5] and non-infectious diseases [6-8] has been known for several years.

VAD in pregnant women is associated with night blindness, severe anaemia, wasting, malnutrition, and reproductive and infectious morbidity [9], and increased risk of mortality 1-2 years following delivery [4]. VAD reduces lymphocyte response [10], and also leads to reduced levels of secretory IgA in mucous membranes and therefore weakens the local barriers to infection

\section{Biomed Central}

(c) 2011 Mulu et al; licensee BioMed Central Ltd. This is an Open Access article distributed under the terms of the Creative Commons Attribution License (http://creativecommons.org/licenses/by/2.0), which permits unrestricted use, distribution, and reproduction in any medium, provided the original work is properly cited. 
$[7,11,12]$. As a result, vitamin A deficient women were found to be more susceptible to illnesses of both infectious such as frequent infection of mucous surface of hallow viscera [4] and non-infectious (eclampsia, preeclampsia, premature rupture of membrane) diseases $[6,13,14]$.

In the era of HIV/AIDS, vitamin A was also postulated to reduce mother to child transmission (MTCT) of HIV by affecting several maternal, fetal, and/or child risk factors for transmission, including the clinical, immunological, or viral stage of HIV disease among pregnant women. Vitamin A has an effect on the integrity of the epithelial lining of the placenta, maternal lower genital tract, or breast. Its deficiency leads to the occurrence of prematurity and low birth weight, and the status of the systemic and digestive mucosal immune systems of the fetus and the child $[15,16]$. Observational studies in sub-Saharan Africa have shown that, low serum vitamin A levels in HIV-infected women to be associated with significantly increased rates of MTCT of HIV $[17,18]$ and infant mortality $[17,19]$. On the contrary, randomized trials of vitamin A supplementation have found that, vitamin A supplementation increases the risk of MTCT [20,21] and can increase mortality in some children born to HIV positive mothers. Vitamin A supplementation in HIV-infected children, on the other hand, has been associated with protective effects against mortality and morbidity, similar to that seen in HIVnegative children [22].

In Ethiopia, studies on VAD in the general population and among pregnant women are scant, despite decades of documentation of VAD as a major public health problem affecting up to $40 \%$ of pregnant women [23-25]. Recently, VAD has also been reported as a severe public health problem among tuberculosis [26] and diarrheic [27] patients infected with HIV. There are no studies examining serum vitamin A status of HIV-infected pregnant women in northwest Ethiopia. Therefore, the present study aimed to determine the level of serum vitamin A among pregnant women with and without HIV infection in tropical settings of Northwest Ethiopia.

\section{Methods}

\section{Subjects and settings}

Pregnant women who visited the antenatal clinic of the University of Gondar Hospital between March and June 2005 in their first trimester for routine antenatal care follow-ups were approached for recruitment. The Hospital is a tertiary level teaching and service rendering hospital that provides health service for over 5 million inhabitants in Northwest Ethiopia. Healthy non pregnant women, who were living in the same geographic locale as pregnant participants, were recruited from voluntary blood donors and served as control subjects.
Informed consent was obtained from the study participants and approved by the Research Ethics Committee of the University of Gondar. None of the subjects had cirrhosis and none of them received vitamin A supplementation.

\section{Anthropometric data}

Body weight and height was measured to the nearest 0.1 $\mathrm{kg}$ on an electronic digital scale and to the nearest 0.1 $\mathrm{cm}$, respectively. Body mass index (BMI) was calculated and used to determine the nutritional status of the study subjects [28], though it is not a surrogate for nutritional assessment during pregnancy.

\section{Blood collection and HIV screening}

About $5 \mathrm{ml}$ of venous blood was collected from each subject as per the routine antenatal care follow up of the pregnant women in the morning but fasting status was not ascertained. After clot was retracted, the blood samples were centrifuged and sera were separated from the cells following standard procedures and stored at $-40^{\circ} \mathrm{C}$ until tested. The sera were tested for presence of HIV-1 antibodies using rapid HIV-1 diagnostic test kits (Abbott, Belgium) with a sensitivity of $99.9 \%$ and specificity of $98 \%$ following the manufacturers' instructions. The results were interpreted following the current national algorithm for screening of HIV-1 infection [29]. CD4 cells count was not measured and none of the study subjects was on antiretroviral therapy because of lack of access in the setting during the study period. Pre and post HIV test counselling was provided to patients and controls as per the routine program.

\section{Biochemical analysis}

Serum level of retinol (vitamin A), albumin, total protein and total cholesterol were determined following standard procedures and briefed as follows:

Serum vitamin A: Serum retinol was determined using high performance liquid chromatography (HPLC) according to the method of Arroyave et al [30] utilizing a Shiseido HPLC system (Shiseido Co. Ltd., Tokyo, Japan) which consisted of a separation by a reverse phase column (Capcell Pak C18 MG S-5, $3 \times 250$ mm, $5 \mu \mathrm{m}$, Shiseido, Japan) and ultraviolet detection using methanol as a mobile phase system. The flow rate was adjusted at $500 \mu \mathrm{l} / \mathrm{min}$ with column temperature set at $40^{\circ} \mathrm{C}$. Serum was deproteinised with an alcoholic solution of retinyl acetate and extracted into hexane. The organic layer was separated, evaporated to dryness under a steam of nitrogen, reconstituted in methanol and injected into the HPLC system with a detection wave length set at $325 \mathrm{~nm}$. All extraction procedures were carried out under reduced light in order to prevent oxidation of the compounds. Pooled human sera were 
used to measure intra and inter-assay coefficients of variation in laboratory analyses for serum retinol and found to be $6.5 \%$ and $3.3 \%$, respectively. VAD was defined as serum retinol level below $<0.7 \mu \mathrm{mol} / \mathrm{l}$ or $20 \mathrm{mg} / \mathrm{dl}$ [1].

\section{Serum albumin}

Serum albumin was determined by end point colorimetric assay in which at $\mathrm{pH}$ value of 4.2 albumin display a sufficiently cationic character to be able to bind with bromcresol green (BCG), an anionic dyestuff, to form a blue green complex. The intensity of the blue green colour is directly proportional to the concentration of albumin and was determined photometrically (AUTOLAB PM 4000/3, Analyser Medical System, Italy). The analytical sensitivity (lower detection limit) of the assay which represents the lowest measurable albumin concentration that can be distinguished from zero is $0.2 \mathrm{~g} /$ dl or $2 \mathrm{gm} / \mathrm{l}$. Hypoalbuminemia was defined as serum albumin level below $3.5 \mathrm{gm} / \mathrm{dl}$ or $35 \mathrm{gm} / \mathrm{l}$ [31].

\section{Total Protein}

Total serum protein (TSP) was determined by enzymatic reaction sequence in which protein in serum forms a blue coloured complex when reacted with cupric ions in an alkaline solution (Teco Diagnostics, USA). The intensity of the violet colour was proportional to the amount of protein present when compared to a solution with known protein concentration and was determined photometrically (AUTOLAB PM 4000/3, Analyser Medical System, Italy). Hypoproteinemia was defined as serum protein level below $6.2 \mathrm{gm} / \mathrm{dl}$ or $62 \mathrm{gm} / \mathrm{l}$ [31].

\section{Total Cholesterol}

Total cholesterol was determined by enzymatic colorimetric test using cholesterol esterase and cholesterol oxidase. Briefly, cholesterol was converted to cholest-4en 3-one and hydrogen peroxide by oxygen with the aid of cholesterol esterase. The produced hydrogen peroxide under the catalytic action of peroxidise formed a red dyestuff when reacted with 4- aminoantipyrine and phenol (Biocon Diagnostic, Germany). The colour intensity was directly proportional to the concentration of cholesterol and was determined photometrically (AUTOLAB PM 4000/3, Analyser Medical System, Italy). The analytical sensitivity (lower detection limit) of the assay which represents the lowest measurable cholesterol concentration that can be distinguished from zero was $\mathrm{mg} /$ $\mathrm{dl}(0.08 \mathrm{mmol} / \mathrm{Lt})$. Hypocholesterolemia was defined as serum level below $154 \mathrm{mg} / \mathrm{dl}$ [31]. Cholesterol level of below $200 \mathrm{mg} / \mathrm{dl}$ was considered as indicator for the absence of lipid metabolic disturbance and cholesterol level of 200-300 mg/dl with HDL cholesterol below 35 $\mathrm{mg} / \mathrm{dl}$ and above $300 \mathrm{mg} / \mathrm{dl}$ is considered as indicator for the presence of lipid metabolic disturbance.

\section{Quality control}

In all cases commercially available control materials with established values were used for quality control purpose and no failure was observed to obtain the assigned values. In addition, pooled sera were used to measure intra and inter-assay coefficients of variation in laboratory analyses for serum retinol and found to be less than $5 \%$. Sufficient sera for the determination of albumin, protein and cholesterol were only found for the 107 pregnant women. And also it was not possible to find extra sera in the control group.

\section{Data analysis}

Data were analyzed using SPSS version 17 statistical package (SPSS, Inc., Chicago, IL, USA). The significance of differences in the serum vitamin A, total protein, albumin and total cholesterol levels between pregnant women with or without HIV infection and healthy controls was evaluated using a one way analysis of variance with post hoc Tukey test to determine pairs of means which differ significantly. In all cases a P value of $<0.05$ was considered statistically significant.

\section{Results}

A total of 423 pregnant women were included in this study. Among the 423 pregnant women, 44 (10.4\%) were infected with HIV. From the total of 55 non pregnant voluntaries blood donors, who were living in the same geographic locale with the pregnant women, $30(54.5 \%)$ were found to be HIV positive. The mean age of pregnant and the non pregnant women was $25.38 \pm 5.68$ (range $16-45$ years) and $28.07 \pm 7.2$ (range 18-41 years), respectively. The mean age of pregnant women with and without HIV infection was $25.50 \pm 4.90$ (range 18-42 years) and 25.37 \pm 5.76 (range 16-45 years), respectively. Whereas mean age of asymptomatic HIV positive healthy non pregnant women and healthy HIV negative controls was $29.57 \pm$ 6.77 (range 18-38 years) and 26.28 \pm 5.9 (range 18-41 years), respectively, with no significant difference in age distributions $(P$ value $>0.05)$.

Table 1 shows the concentrations of serum retinol in pregnant women and non pregnant controls. After controlling for total serum protein, albumin and demographic variables, the mean \pm SD serum vitamin $\mathrm{A}$ in HIV seropositive pregnant women $(0.96 \pm 0.42 \mu \mathrm{mol} / \mathrm{L})$ was significantly lower than that in pregnant women without $\mathrm{HIV}$ infection $(1.10 \pm 0.45 \mu \mathrm{mol} / \mathrm{L}, \mathrm{P}<0.05)$. A significant interaction between HIV positive group and level of TSP was observed. To further explore this interaction, we compared the mean retinol concentrations of those with a high TSP and those with hypoproteinemia by HIV status. The mean retinol concentration was significantly lower in the HIV positive pregnant women 
Table 1 Socio-demographic characteristics and serum parameters of pregnant and non pregnant women

\begin{tabular}{|c|c|c|c|c|}
\hline \multirow[t]{2}{*}{ Characteristics } & \multicolumn{2}{|c|}{ Pregnant $(n=423)$} & \multicolumn{2}{|c|}{ Non pregnant $(n=55)$} \\
\hline & With HIV (44) & Without HIV (379) & With HIV (30) & Without HIV (25) \\
\hline Age (years) & $25.50 \pm 4.90$ & $25.37 \pm 5.76$ & $29.57 \pm 6.7$ & $26.28 \pm 7.4$ \\
\hline $\mathrm{BMI}\left(\mathrm{kg} / \mathrm{m}^{2}\right)$ & $23.56 \pm 3.04^{\pi}$ & $23.45 \pm 3.05^{\natural}$ & $18.67 \pm 4.31$ & $20.55 \pm 3.1$ \\
\hline Serum retinol $(\mu \mathrm{mol} / \mathrm{L})$ & $0.96 \pm 0.42^{*}$ & $1.10 \pm 0.45^{\$}$ & $0.74 \pm 0.39^{\S}$ & $1.18 \pm 0.59$ \\
\hline £Albumin gm/dl & $3.65 \pm 0.68^{*}$ & $3.99 \pm 85$ & ND & ND \\
\hline £Total protein (gm/dl) & $6.12 \pm 0.94$ & $5.99 \pm 1.22$ & ND & ND \\
\hline £Cholesterol (mg/dl) & $144.5 \pm 54.20^{*}$ & $168 \pm 51.52$ & ND & ND \\
\hline
\end{tabular}

Keys: IP value $<0.001$ versus HIV positive non pregnant women and HIV negative non pregnant women; *P value $=0.04$ versus HIV negative pregnant women, ${ }^{\$} \mathrm{P}$ value $=0.02$ versus HIV positive non pregnant women, ${ }^{\S} \mathrm{P}$ value $=0.000$ verse HIV negative non pregnant women, ND: Not done, $£ \mathrm{~N}=107$

with high TSP $(\mathrm{P}<0.05)$ but was not significantly different from that of HIV negative group.

The mean concentration of serum vitamin A was not significantly different between HIV positive pregnant women and HIV positive non pregnant women. It was also not significantly different between HIV negative pregnant women and HIV negative apparently health non pregnant controls. However, mean concentration of serum vitamin A level was significantly higher in HIV positive pregnant women $(0.96+/-0.42)$ than that in HIV positive non pregnant women $(0.74+/-0.39)(P=0.02)$. Irrespective of pregnancy, HIV positive women had significantly lower serum concentration of vitamin A compared with HIV negative women $(\mathrm{P}<0.05)$. Non pregnant women without HIV infection had significantly higher serum vitamin A concentration compared to non pregnant controls with HIV infection, $\mathrm{P}<0.001$. The mean serum vitamin A level of HIV positive pregnant women was $0.96 \pm 0.42$ where as the mean serum vitamin A level of HIV negative pregnant mothers was $1.1 \pm$ 0.45 . This mean difference in serum vitamin A level between the groups was statistically significant $(P=0.01)$.

Of the total 478 pregnant and non pregnant women (including controls), VAD was observed in 99 (20.7\%) with a serum retinol level of less than $0.7 \mu \mathrm{mol} / \mathrm{L}$ (Table 2 ). The proportion of HIV positive pregnant women with serum retinol levels consistent with severe $(0.00$ $0.34 \mu \mathrm{mol} / \mathrm{L})$ and moderate $(0.35-0.69 \mu \mathrm{mol} / \mathrm{L}) \mathrm{VAD}$ was significantly higher than that in healthy controls (without HIV infection) and asymptomatic HIV infected controls $(p<0.05)$. From the total 74 HIV positive women, $33.8 \%(25 / 74)$ had a retinol level of less than $0.7 \mu \mathrm{mol} / \mathrm{L}$ and were vitamin A deficient.
Of 423 pregnant women, VAD was observed in 78 which accounted for $18.4 \%$ prevalence rate of VAD among pregnant women. Out of the 44 pregnant women with HIV infection, 11 (25\%) were deficient for vitamin A with serum retinol level of below $0.7 \mu \mathrm{mol} / \mathrm{L}$ of which, $3(6.8 \%)$ and 8 (18.2) had moderate (0.35-0.69 $\mu \mathrm{mol} / \mathrm{L})$ and severe $(0.00-0.34 \mu \mathrm{mol} / \mathrm{L})$ vitamin A deficiency, respectively. Similarly, among 30 asymptomatic HIV infected non pregnant voluntaries, 46.7\% (14/30) were vitamin A deficient with serum retinol level of below $0.7 \mu \mathrm{mol} / \mathrm{L}$, of which, $4(13.3 \%)$ and $10(33.3 \%)$ had moderate $(0.35-0.69 \mu \mathrm{mol} / \mathrm{L})$ and severe $(0.00-0.34$ $\mu \mathrm{mol} / \mathrm{L})$ vitamin A deficiency, respectively.

As indicated in Table 1 and 3, serum albumin and cholesterol concentrations were significantly lower in the HIV positive pregnant women compared with HIV negative pregnant women $(\mathrm{P}<0.001)$. There was no significant difference in TSP value within the two groups $(P=0.06)$. Although the mean serum levels of vitamin A decreases with age, the difference between was not statistical significance $(P=0.07)$ (Table 4$)$. Mean serum vitamin A level was significantly lower among women with $\mathrm{BMI}<18.5 \mathrm{~kg} / \mathrm{m}^{2}$ than among those with BMI of $18.5 \mathrm{~kg} / \mathrm{m}^{2}$ or above, $\mathrm{P}$ value $=0.024$ (Table 4$)$. Although, BMI is not a surrogate for nutritional assessment during pregnancy, undernourished (BMI $<18.5$ $\mathrm{kg} / \mathrm{m}^{2}$ ) was observed in $4 \%$ of the pregnant women. Body weight and BMI were significantly lower in HIV infected pregnant woman compared to HIV non infected pregnant woman $(\mathrm{P}<0.05)$. Undernourished $\left(\mathrm{BMI}<18.5 \mathrm{~kg} / \mathrm{m}^{2}\right)$ was observed in $50 \%$ of asymptomatic HIV positive non pregnant woman (data not shown).

Table 2 Vitamin A deficiency in pregnant and non pregnant women by HIV serostatus

\begin{tabular}{lccccccc}
\hline Vitamin A Status & \multicolumn{4}{c}{ Pregnant women } & \multicolumn{3}{c}{ Non pregnant women } \\
\cline { 2 - 8 } & HIV +ve & HIV -ve & OR $(\mathbf{9 5} \% \mathrm{Cl})$ & $\boldsymbol{P}$ value & HIV +ve & HIV -ve & OR (95\%Cl) \\
\hline VAD & $11(25)$ & $67(17.7)$ & $2.50(1.38-4.60)$ & 0.002 & $14(46.7)$ & $7(28)$ & \\
Non VAD & $33(75)$ & $312(82.3)$ & $1.30(1.14-1.50)$ & 0.003 & $16(53.3)$ & $18(72)$ & \\
\hline
\end{tabular}

Keys: +ve: Positive; -ve: Negative 
Table 3 Prevalence of micronutrient deficiencies and distribution of pregnant women and controls by HIV infection and serum status of micronutrients

\begin{tabular}{|c|c|c|c|c|c|c|c|c|c|}
\hline \multirow[t]{2}{*}{ Parameters } & \multirow[t]{2}{*}{$\begin{array}{l}\text { Cutoff } \\
\text { value }\end{array}$} & \multicolumn{2}{|c|}{$\begin{array}{c}\text { HIV positive } \\
\text { pregnant women } \\
(44)\end{array}$} & \multicolumn{2}{|c|}{$\begin{array}{c}\text { HIV negative } \\
\text { pregnant women } \\
\text { (379) }\end{array}$} & \multicolumn{2}{|c|}{$\begin{array}{c}\text { HIV positive } \\
\text { non pregnant women } \\
(30)\end{array}$} & \multicolumn{2}{|c|}{$\begin{array}{l}\text { HIV negative non } \\
\text { pregnant controls } \\
(25)\end{array}$} \\
\hline & & Deficient & $\begin{array}{c}\text { Non } \\
\text { deficient }\end{array}$ & Deficient & $\begin{array}{c}\text { Non } \\
\text { deficient }\end{array}$ & Deficient & $\begin{array}{c}\text { Non } \\
\text { deficient }\end{array}$ & Deficient & $\begin{array}{c}\text { Non } \\
\text { deficient }\end{array}$ \\
\hline Vitamin A & $0.7 \mu \mathrm{mol} / \mathrm{L}$ & $\begin{array}{c}33(75)^{*} \\
0.79 \pm 0.32^{* *}\end{array}$ & $\begin{array}{c}11(25) \\
1.45 \pm 0.25\end{array}$ & $\begin{array}{c}234(61.7) \\
0.82 \pm(0.26)^{\$}\end{array}$ & $\begin{array}{c}145(31.8) \\
1.54 \pm(0.29)\end{array}$ & $\begin{array}{c}26(86.7) \\
0.63 \pm 0.28)\end{array}$ & $\begin{array}{c}4(13.3) \\
1.45 \pm(0.16)\end{array}$ & $\begin{array}{c}12(48) \\
0.68 \pm(0.27)\end{array}$ & $\begin{array}{c}13(52) \\
1.6 \pm(0.39)\end{array}$ \\
\hline $\begin{array}{l}\text { TSP } \\
(107)\end{array}$ & $6.2 \mathrm{gm} / \mathrm{dl}$ & $\begin{array}{c}8 / 13(61) \\
5.6 \pm(0.68)\end{array}$ & $\begin{array}{c}5 / 13(39) \\
7.1 \pm(0.35)\end{array}$ & $\begin{array}{c}56 / 94(59) \\
5.2 \pm(0.55)\end{array}$ & $\begin{array}{c}38 / 94(41) \\
7.2 \pm(0.85)\end{array}$ & ND & ND & ND & ND \\
\hline Albumin (107) & $3.5 \mathrm{gm} / \mathrm{dl}$ & $\begin{array}{c}6 / 33(18) \\
3.06 \pm(0.39)\end{array}$ & $\begin{array}{c}27 / 33(82) \\
3.04 \pm(0.51)\end{array}$ & $\begin{array}{c}7 / 74(9) \\
4.15 \pm(0.39)\end{array}$ & $\begin{array}{c}67 / 72(91) \\
4.3 \pm(0.64)\end{array}$ & ND & ND & ND & ND \\
\hline $\begin{array}{l}\text { Cholesterol } \\
(107)\end{array}$ & $154 \mathrm{mg} / \mathrm{dl}$ & $\begin{array}{c}9 / 13(69 \\
119.8 \pm(28)\end{array}$ & $\begin{array}{c}4 / 13(31) \\
200.5 \pm(59)\end{array}$ & $\begin{array}{c}38 / 94(40) \\
119.5 \pm(20.8)\end{array}$ & $\begin{array}{c}56 / 94(60) \\
200.8 \pm(38)\end{array}$ & ND & ND & ND & ND \\
\hline
\end{tabular}

Keys: *Number (\%), ** Mean $\pm \mathrm{SD},{ }^{5} \mathrm{P}$ value $<0.05$ versus HIV negative non pregnant controls, ND: Not done

\section{Discussion}

This cross-sectional study is the first of its kind in Ethiopian pregnant mothers with and without HIV infection in which serum levels of vitamin A has been measured. In this study, we found biochemical evidence that VAD was common in pregnant women, regardless of HIV status in Northwest Ethiopia. VAD has been defined as a public health problem when the prevalence of VAD, judged by serum retinol less than $0.7 \mu \mathrm{mol} / \mathrm{l}$, among pregnant women is $15 \%$ [32]. In the present study, the overall prevalence of VAD among pregnant and non pregnant women was $18.4 \%$, thus indicating a marginally major public health problem but neglected among these pregnant women in tropical settings of Northwest Ethiopia.

Due to multiple guidelines and lack of precise recommendation, nutritional surveys have used diverse reference values as a cut off indicating deficient vitamin A status. This in turn has jeopardized comparability of results of population-based prevalence studies. Although international consensus has yet to be establishes, serum retinol concentration below a cutoff of $1.05 \mu \mathrm{mol} / \mathrm{l}$ has been proposed to reflect low vitamin A status among pregnant and lactating women [21]. While the distribution of serum

Table 4 Relationship between serum vitamin A level with age and body mass index (BMI)

\begin{tabular}{clll}
\hline Variables & $\mathbf{N}$ & $\begin{array}{l}\text { Serum retinol }(\boldsymbol{\mu m o l} / \mathbf{L}) \\
\text { Mean } \pm \text { SD }\end{array}$ & $P$ value \\
\hline Age (Years) & & & \\
$<20$ & 20 & $1.09+0.44$ & 0.070 \\
$21-30$ & 274 & $1.06+0.45$ & \\
$31-40$ & 73 & $1.04+0.48$ & \\
$41+$ & 4 & $0.88+0.57$ & \\
BMI $\left(\mathrm{kg} / \mathrm{m}^{2}\right)$ & & & 0.024 \\
$<18.5$ & 34 & $0.89 \pm 0.43$ & \\
$>18.5$ & 444 & $1.08 \pm 0.45$ &
\end{tabular}

retinol concentrations below appropriate cut-offs are considered to reflect inadequate states of vitamin A nutriture, a low biochemical concentration of retinol in circulation is not considered a VAD. Thus, it is difficult to compare rates of VAD among previous studies. Even with this limitation, the $18.4 \%$ prevalence of VAD in this study population of pregnant women is a lower rate compared with previous report in a settings where about $40 \%$ rate of VAD has been reported [33] and previous reports from Bangladesh where VAD as high as $69 \%$ had been reported $[34,35]$. However, it is in agreement with a South African study which showed 16\% VAD among mothers during the first 6 months of delivery [36]. The high rate of VAD in our study group could be due to dietary factors including inadequate vitamin A intake in Ethiopian population [24] and the relatively poor socio-economic and nutritional status of Ethiopian mothers compared with mothers in some other parts of developing nations.

This study showed that, HIV positive pregnant women had significantly lower mean serum retinol concentration than did HIV negative pregnant women $(P<0.05)$. This finding was consistent with a study from Malawi [37], Rwanda [38,39] and Zimbabwe [40]. The low levels of serum vitamin A might be due to a low release of vitamin A from the liver during HIV infection, which would lead to low levels of vitamin A in the plasma despite the body having enough vitamin A liver stores [16]. The mean serum vitamin A level of HIV seropositive pregnant women was $0.96 \pm 0.42$ where as the level in HIV negative pregnant mother was $1.1 \pm 0.45$ ( $\mathrm{P}$ value $<0.001)$. This significant difference in serum vitamin A between HIV positive and negative pregnant women remained after measures of total serum protein, albumin and demographic variables (age, weight, BMI) were controlled for, which was also in agreement with a Zimbabwean study [40]. Low serum vitamin A level among HIV infected pregnant women was reported to be associated with a higher risk of vertical transmission 
of HIV [37-39], increased risk of preterm delivery and maternal anaemia [41].

HIV positive women had significantly lower serum concentration of vitamin A compared with HIV negative women $(P<0.01)$, irrespective of pregnancy. Serum retinol may transiently be low due to reduced production of retinol binding protein, which is often observed as part of the acute-phase response to infection [42]. Furthermore, it is also important to note that sub-clinical infection or inflammation has been found to be associated with the reduction of serum retinol level due to reduced production of retinol binding protein [42]. Although, we do not have any indication on the presence of sub-clinical infection on our study group and we did not measure acute inflammatory responses in the present study. It should be noted that, times of blood collections for all pregnant women was their routine antenatal follow up and all participants were healthy. Other possible confounding factors such as intestinal helminths $[42,43]$ may influence serum retinol concentrations as high prevalence of helminthic infection was reported in the study area $[26,27,43]$. Low intake of green vegetables, fruit and dairy products could also be contributing factors for the low serum vitamin A level, as the staple food in Northwest Ethiopian is mainly a pancake named enjera made from a cereal called Tef (Eragrostis teff). Usually the enjera is eaten with stew made from legumes (mainly pea and beans).

In this study, overall prevalence of hypoalbuminaemia in pregnant women was relatively low (12\%). This finding is similar to that of an earlier study carried out among Ethiopian pregnant mothers in the same locality [25]. No significant interaction between HIV sero-positive status during pregnancy and level of TSP was observed among vitamin A deficient women suggesting the lack of contribution of general protein-energy undernourished to VAD. In the present study, undernourished (BMI $<18.5 \mathrm{~kg} / \mathrm{m}^{2}$ ) women were found to have statistically significantly lower serum retinol level than well-nourished (BMI $>18.5 \mathrm{~kg} / \mathrm{m}^{2}$ ) women. This is consistent with other studies from Bangladesh and Nepal $[9,35]$.

\section{Conclusions}

The present study shows that VAD among pregnant women in tropical settings of northwest Ethiopia is a major public health problem. Irrespective of pregnancy, HIV positive women had significantly lower serum concentration of vitamin A levels compared with HIV negative women. Considering the possible implications of VAD during pregnancy, we recommend multivitamin (which has a lower level of vitamin A) supplementation in the care and management of pregnant women with or without HIV infection.

\section{Limitations}

This study has the following basic limitations. First, due to the presence of multiple guidelines and lack of precise recommendation, nutritional surveys have used diverse reference values as a cut off between normal and deficient vitamin A status. As a result, VAD in this study was defined based on WHO recommendation which are wildly accepted and used [1], as serum retinol level below $0.7 \mu \mathrm{mol} / \mathrm{L}$. Second, micronutrient status is difficult to assess in the presence of infection, because biochemical indicators of several micronutrients are affected by the acute phase response. For instance, albumin, and retinol are "negative" responders, which increase during an acute phase response markers [36]. Thus, since in the present study, acute phase response (for example, C-reactive protein (CRP) and alpha 1- acid glycoprotein (AGP)) were not measured and controlled. Such markers were not measured in these subjects, due to the lack of laboratory facility. Hence, the results may be confounded by increased rates of acute phase response measures in the HIV positive women and may lead to an underestimation of vitamin $\mathrm{A}$ and albumin status. Third, body mass index (BMI) was used to determine the nutritional status of the study subjects though it is not a surrogate for nutritional assessment during pregnancy. Lastly, the low number of sample size among the control group resulted inflated HIV prevalence and hence might influence the results.

\section{Acknowledgements}

We would like to thank the study participants. The study was supported partly by University of Gondar, Ethiopia and partly by Sasakawa Scientific Foundation, Japan.

\section{Author details}

${ }^{1}$ Department of Microbiology, Immunology and Parasitology, College of Medicine and Health Sciences, University of Gondar, P. O. Box 196, Gondar, Ethiopia. ${ }^{2}$ Institute of Virology, Faculty of Medicine, University of Leipzig, Johannisallee 30, 04103, Leipzig, Germany. ${ }^{3}$ Department of Medical Laboratory Technology, College of Medicine and Health Sciences, University of Gondar P. O. Box 196, Gondar, Ethiopia. ${ }^{4}$ Division of Nutrition and Food Science, Ochanomizu University, Tokyo 112-8610, Japan. ${ }^{5}$ Department of Science and Network Direction, National Institute for Food Control, 15A Phan Huy Chu, Hanoi, Vietnam. ' ${ }^{6}$ epartment of Human Anatomy, College of Medicine and Health Sciences, University of Gondar, P.O. Box 196, Gondar, Ethiopia. ${ }^{7}$ Department of Medicine, Howard University Hospital, Howard University. ${ }^{8}$ International Nutrition, Department of Food and Nutritional Sciences, Graduate School of Human Life Sciences, Jumonji University, 2-1-28 Sugasawa, Niiza-City, Saitama 352-8510, Japan. ${ }^{9}$ Department of Preventive Environment and Nutrition, Institute of Health Biosciences, The University of Tokushima, Japan.

\section{Authors' contributions}

AM: conception of the research idea, study design, data collection and analysis and interpret the data and the draft of the manuscript; AK: conception of the research idea, study design, data collection and analysis, interpret the data and reviewed the manuscript; KH, BT, GY: data collection, part of laboratory work, data analysis and reviewed the manuscript; SY, MN, $N N$, FO: data analysis and interpretation and reviewed the manuscript; $A B$, YW: study design, interpret the data and reviewed the manuscript. All authors have read and approved the final version of the manuscript. 


\section{Competing interests}

No competing interests exist. This manuscript has not been published before or submitted elsewhere for publication.

Received: 17 March 2011 Accepted: 15 July 2011

Published: 15 July 2011

\section{References}

1. World Health Organization: Global prevalence of vitamin A deficiency in populations at risk 1995-2005, Global Database on Vitamin A Deficiency. Geneva: WHO; 2009

2. Katz J, Khatry SK, West KP Jr, et al: Night blindness during pregnancy and lactation in rural Nepal. J Nutr 1995, 125:2122-2127.

3. World Health Organization: Trace elements in human nutrition and health. WHO Geneva: WHO; 1996, 72-104.

4. Scrimshaw NS, San Giovanni JP: Synergism of nutrition, infection, and immunity: an overview. Am J Clin Nutr 1997, 66(suppl):464S-77S.

5. Ziari SA, Mireles VL, Cantu CG, et al: Serum vitamin A, vitamin E, and betacarotene levels in preeclamptic women in northern Nigeria. Am J Perinatol 1996, 13:287-2911

6. Semba RD, Miotti PG, Chiphangwi JD, et al: Maternal vitamin A deficiency and infant mortality in Malawi. J Trop Pediatr 1998, 44:232-234.

7. Ross AC: Vitamin A status; relationship to immunity and the antibody response. Proc Soc Exp Biol Med 1992, 200:303-320.

8. Christian P, Schulze K, Stoltzfus RJ, et al: Hyporetinolemia, illness symptoms, and acute phase protein response in pregnant women with and without night blindness. Am J Clin Nutr 1998, 67:1237-1243.

9. Christian P, West KP, Khatry SK, et al: Night blindness of pregnancy in rural Nepal-nutritional and health risks. Int J Epidemiol 1998, 27:231-237.

10. Semba RD: Vitamin A and immunity to viral, bacterial and protozoan infections. Proc Nutr Soc 1999, 58:719-727.

11. Semba RD: Vitamin A, immunity and infection. Clin Infect Dis 1994, 19:489-499.

12. Sommer A, West KP Jr: Vitamin A deficiency: health, survival, and vision. New York: Oxford University Press; 1996

13. Mikhail MS, Anyaegbunam A, Garfinkel D, et al: Pre-eclampsia and antioxidant nutrients: decreased plasma levels of reduced ascorbic acid, alpha-tocopherol, and beta-carotene in women with pre-eclampsia. Am J Obstet Gynecol 1994, 171:150-157.

14. Barrett BM, Sowell A, Gunter E, et al: Potential role of ascorbic acid and beta-carotene in the prevention of preterm rupture of fetal membranes. Int J Vit Nutr Res 1994, 64:192-195.

15. Fawzi WW, Hunter DJ: Vitamins in HIV disease and vertical transmission. Epidemiol 1998, 9:457-466.

16. Fawzi WW: Nutritional factors and vertical transmission of HIV-1. Epidemiology and potential mechanisms. Ann N Y Acad Sci 2000, 918:99-114.

17. Dushimimana A, Graham MN, Humphrey JH, et al: Maternal vitamin A levels and HIV-related birth outcome in Rwanda. Int Conf AIDS Amsterdam 1992, Abstract no POC 4221.

18. Semba RD, Miotti PG, Chiphanwi JD, et al: Maternal vitamin A deficiency and mother to child transmission of HIV-1. Lancet 1994, 343:1593-1597.

19. Semba RD, Miotti $P G$, Chipangwi JD, et al: Infant mortality and vitamin $A$ deficiency during human immunodeficiency virus infection. Clin Infect Dis 1995, 21:966-972.

20. Greenberg BI, Semba RD, Vink, et al: Vitamin A deficiency and maternalinfant transmission of HIV in two metropolitan areas in the United States. AIDS 1997, 11:325-332.

21. Landesmand S: Vitamin A relationships to mortality in HIV disease and effects on HIV infection and late breaking studies. Bethesda, National Institutes of Health (Lawton Chiles International House) 1996.

22. Coutsoudis A, Bobat RA, Coovadia HM, et al: The effects of vitamin A supplementation on the morbidity of children born to HIV-infected women. Am J Public Health 1995, 85:1076-1081.

23. Thein M: Study of milk vitamin $A$, serum vitamin $A$ and serum protein levels of lactating mothers of Bochessa village, rural Ethiopia. East Afr Med J 1979, 56:542-547.

24. Demissie M, Omer OA, Lindjorn B, Hombergh J: The Epidemiology and Ecology of Health and Disease in Ethiopia.Edited by: Nutrition In: Berhane Y, Hailemariam D, Kloos (Eds). Shama Books, Addis Ababa, Ethiopia; 2006:
25. Yared Wondmikun: Dark adaptation pattern of pregnant women as an indicator of functional disturbance at acceptable serum vitamin A levels. Eur J Clin Nutr 2002, 56:462-466.

26. Kassu A, Yabutani T, Mulu A, et al: Serum zinc, copper, selenium, calcium, and magnesium levels in pregnant and non-pregnant women in Gondar, Northwest Ethiopia. Biol Trace Elem Res 2008, 122:97-106.

27. Kassu A, Andualem B, Van Nhien N, et al: Vitamin A deficiency in patients with diarrhea and HIV infection in Ethiopia. Asia Pac J Clin Nutr 2007, 16(Suppl 1):323-328.

28. World Health organization: Physical status: the use and interpretation of anthropometry. In World Health organization Tech Rep Ser. Volume 854 Report of WHO Expert Committee; 1995:1-452, Geneva.

29. Ethiopian Health and Nutrition Institute: Manual for HIV-1 Diagnosis. 2002, $\mathrm{MOH}$, Addis Ababa, Ethiopia.

30. Arroyave $\mathrm{G}$, Chichester $\mathrm{CO}$, Flores $\mathrm{H}$, et al: Biochemical methodology for the assessment of vitamin A status: a report of the International Vitamin A Consultative Group (IVACG). Nutrition Foundation, Washington DC, USA; 1982.

31. Tietz NW: Fundamentals of Clinical Chemistry., Pa: W.B. Saunders. 1995 Philadelphia 299.

32. Peggy CPapathakis, Nigel CRollins, Caroline JChantry, et al: Micronutrient status during lactation in HIV-infected and HIV-uninfected South African women during the first 6 months after delivery. Am J Clin Nutr 2007, 85:182-192.

33. Yared Wondmikun: Lipid-soluble antioxidants status and some of its socio-economic determinants among pregnant Ethiopians at the third trimester. Public Health Nutr 2005, 8:582-587.

34. Ahmed F, Mahudal I, Sattar A, et al: Anaemia and vitamin A deficiency in poor urban pregnant women of Bangladesh. Asia Pac J Cli Nutr 2003, 12:460-466.

35. Vanessa Lee, Faruk Ahmed, Shoko Wada, et al: Extent of vitamin A deficiency among rural pregnant women in Bangladesh. Public Health Nutr 2003, 11:1326-1331.

36. Semba RD, Miotti $P G$, Chipangwi JD, et al: Maternal vitamin A deficiency and mother-to-child transmission of HIV-1. Lancet 2003, 343:1593-1597.

37. Semba RD, Miotti PG, Chipangawi JD, et al: Infant mortality and maternal vitamin A deficiency during human immunodeficiency virus infection. Clin Infect Dis 1995, 21:966-972.

38. Graham N, Bulterys M, Chao A, et al: Effect of maternal vitamin A deficiency on infant mortality and perinatal HIV transmission. National Conference on Human Retroviruses and Related Infection, MD, 1993 December 12-16, Baltimore.

39. Friis $H$, Gomo E, Koestel $P$, et al: HIV and other predictors of serum betacarotene and retinol in pregnancy: a cross-sectional study in Zimbabwe. Am J Clin Nutr 2001, 73:1058-1065.

40. International Vitamin A Consultative Group: 25 year progress in controlling vitamin A deficiency. looking to the future Washington, DC: ILSI; In XX IVACG Meeting Program, 2001 p. 12.

41. Radhikaa MS, Bhaskarama P, Balakrishnaa, et al: Effects of vitamin A deficiency during pregnancy on maternal and child health. BJOG: an International Journal of ObstetGynaecol 2002, 109:689-693.

42. Filteau SM, Tomkins AM: Micronutrients and tropical infections. Trans $R$ Soc Trop Med Hyg 1994, 88:1-3.

43. Nega Berhe, Bente LHalvorsen, Thomas E, et al: Reduced serum concentrations of retinol and alpha -tocopherol and high concentrations of hydroperoxides are associated with community levels of S. mansoni infection and schistosomal periportal fibrosis in Ethiopian school children. Am J Trop Med Hyg 2007, 76:943-949.

\section{Pre-publication history}

The pre-publication history for this paper can be accessed here: http://www.biomedcentral.com/1471-2458/11/569/prepub

\section{doi:10.1186/1471-2458-11-569}

Cite this article as: Mulu et al: Vitamin A deficiency during pregnancy of HIV infected and non-infected women in tropical settings of Northwest Ethiopia. BMC Public Health 2011 11:569. 